\title{
Iridium-Catalyzed C4-Alkylation of 2,6-Di-tert-butylphenol by Using Hydrogen-Borrowing Catalysis
}

\author{
James R. Frost \\ Choon Boon Cheong \\ Timothy J. Donohoe*
}

Department of Chemistry, University of Oxford, Chemical Research Laboratory, Mansfield Road, Oxford, OX1 3TA, UK timothy.donohoe@chem.ox.ac.uk
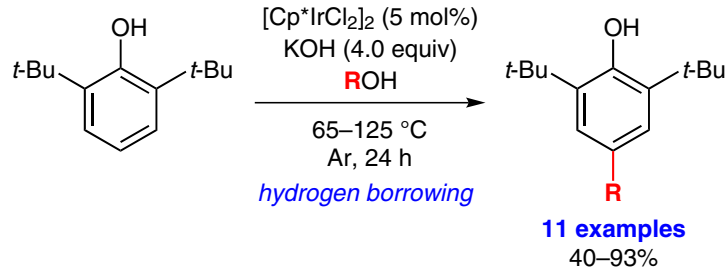

Received: 24.03.2016

Accepted: 02.04.2016

Published online: 12.05 .2016

DOI: 10.1055/s-0035-1561439; Art ID: ss-2016-z0210-op

\section{License terms: (C) (i)}

Abstract An iridium-catalyzed hydrogen-borrowing process has been developed whereby 2,6-di-tert-butylphenol can be alkylated at the C4position by using a range of primary alcohols (11 examples, 40-93\% yield). Following this, a selection of the products obtained underwent retro-Friedel-Crafts reactions to provide para-substituted phenols, which could potentially undergo further synthetic manipulations.

Key words iridium, catalysis, hydrogen borrowing, phenols, alkylation

The efficiency of many synthetic organic procedures is limited by the need to perform separate sequential oxidation and reduction (redox) steps to generate further molecular complexity. As a result, hydrogen-borrowing catalysis has emerged as a useful alternative to achieve $\mathrm{C}-\mathrm{C}$ bond formation. This concept relies on the use of an appropriate transition-metal catalyst to carry out oxidation and reduction steps in a one-pot process, with bond formation between the reactive intermediates generated in situ (Scheme 1 ). The entire process involves no net change in oxidation state and therefore constitutes a powerful method for rapid $\mathrm{C}-\mathrm{C}$ bond assembly, avoiding laborious chemical manipulations and toxic reagents. ${ }^{1}$

In a recent research program, we have started to develop new reactions relating to hydrogen-borrowing chemistry, with particular focus on the alkylation of methylene ketones to form branched products. ${ }^{2}$ In doing so, we were able to complement this methodology with the synthesis of a host of carboxylic acid derivatives. ${ }^{2 c}$ Our search for new substrates with which to perform hydrogen-borrowing chemistry led us to consider phenols, because this class of molecules contributes widely to numerous industrial processes leading to a variety of consumer products. ${ }^{3}$ However,

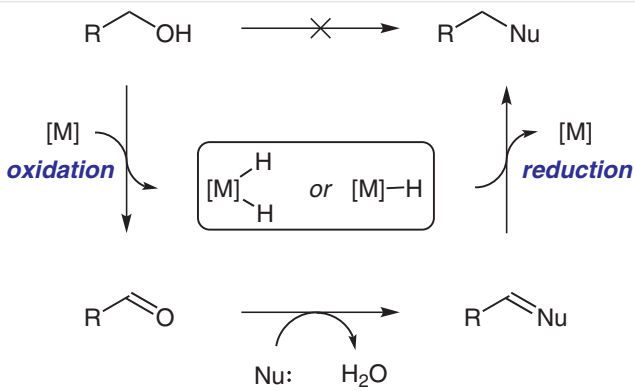

Scheme 1 General scheme for hydrogen-borrowing catalysis

one of the main issues concerning phenol alkylation chemistry is that the reaction can occur on either an oxygen or a carbon atom. Studies by Kornblum and Seltzer ${ }^{4}$ have shown that the alkylation of 2,6-di-tert-butylphenol can be achieved at either the oxygen or the C4-position, the product distribution being affected by changes in the steric nature of the alkyl halide electrophile. Conversely, hydroxymethylation by using formaldehyde and hydroxide base proceeds exclusively at the phenolic carbon positions. This so-called Lederer-Manasse reaction is an effective means of producing C2- and/or C4-hydroxymethylated phenols, depending on the starting phenol used. ${ }^{5}$

Given that hydrogen-borrowing chemistry typically involves the generation of an aldehyde in situ from the corresponding primary alcohol and that it requires a base, we considered that the Lederer-Manasse reaction might be adapted to this chemistry and thereby provide a means to generate various alkylated products instead. We also wondered whether it would be possible to use higher primary alcohols (i.e., those more complex than $\mathrm{MeOH}$ ) in this process. A subsequent search of the literature revealed that hydrogen-borrowing chemistry involving phenols was relatively underexplored. Recent research by Yi and co-work- 
ers $^{6 a}$ and by Walton and Williams ${ }^{6 \mathrm{~b}}$ has shown that phenols can be alkylated at the C2-position by a dehydrative coupling process, whereas Li's group has reported ${ }^{7}$ cleavage of the $\mathrm{C}-\mathrm{O}$ bond to allow cross-coupling with amines. Here we report our preliminary investigations that have led to the development of a hydrogen-borrowing process that permits C4-alkylation of 2,6-di-tert-butylphenol.

Previous research in our group has shown that $[\operatorname{Ir}(\operatorname{cod}) \mathrm{Cl}]_{2}(\operatorname{cod}=$ cyclooctadiene; $1 \mathrm{~mol} \%)$ and $\mathrm{PPh}_{3}$ ( $4 \mathrm{~mol} \%$ ) in combination with $\mathrm{KOH}$ and $\mathrm{MeOH}$ can be used to $\alpha$-methylate various methylene ketones in good to excellent yield. ${ }^{2 b}$ These conditions were therefore chosen as a starting point for the present study with 2,6-di-tert-butyl- phenol (1) as substrate. Initial application of these conditions pleasingly gave a small quantity of the desired C4-alkylated product $\mathbf{2 a}(6 \%)$ as well as $32 \%$ of unreacted $\mathbf{1}$ (Table 1 , entry 1). Although not isolated, it was clear from its ${ }^{1} \mathrm{H}$ NMR spectrum that the remaining crude material consisted of bisphenol 3 and bi(cyclohexadienylidene)dione 4 . $^{8}$ Product $\mathbf{3}$ presumably resulted from addition of $\mathbf{1}$ to an intermediate $p$-quinone methide generated in situ, ${ }^{9,10}$ which subsequently rearomatized, whereas $\mathbf{4}$ arose by oxidative dimerization of $\mathbf{1}$. To improve the product distribution in favor of 2a, we first chose to vary the amount of $\mathrm{KOH}$. The addition of more base ( 4.0 or 6.0 equiv; entries 2 and 3 ) increased the amount of $\mathbf{2 a}$ to $29 \%$ in both cases. With the

Table 1 Optimization of Conditions for the C4-Alkylation of 2,6-Di-tert-butylphenol

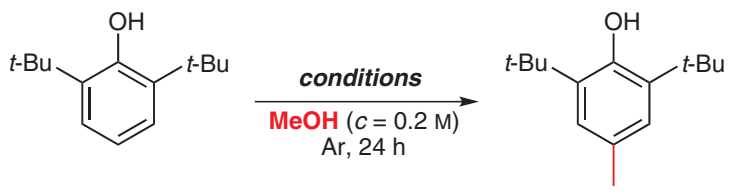

$2 a$

Additional products observed (not isolated):<smiles>CC(C)(C)c1cc(Cc2cc(C(C)(C)C)c(O)c(C(C)(C)C)c2)cc(C(C)(C)C)c1O</smiles><smiles>CC(C)(C)C1=CC(=C2C=C(C(C)(C)C)C(=O)C(C(C)(C)C)=C2)C=C(C(C)(C)C)C1=O</smiles>

\begin{tabular}{|c|c|c|c|c|c|}
\hline \multirow[t]{2}{*}{ Entry } & \multirow[t]{2}{*}{ Precatalyst and ligand } & \multirow[t]{2}{*}{$\mathrm{KOH}$ (equiv) } & \multirow[t]{2}{*}{ Temp $\left({ }^{\circ} \mathrm{C}\right)$} & \multicolumn{2}{|c|}{ Yield ${ }^{\mathrm{a}}(\%)$} \\
\hline & & & & 1 & $2 a$ \\
\hline 1 & {$[\operatorname{lr}(\operatorname{cod}) \mathrm{Cl}]_{2}(1 \mathrm{~mol} \%), \mathrm{PPh}_{3}$ (4 mol\%) } & 2 & 65 & 32 & 6 \\
\hline 2 & {$[\operatorname{lr}(\operatorname{cod}) \mathrm{Cl}]_{2}(1 \mathrm{~mol} \%), \mathrm{PPh}_{3}$ (4 mol\%) } & 4 & 65 & 15 & 29 \\
\hline 3 & {$[\mathrm{Ir}(\operatorname{cod}) \mathrm{Cl}]_{2}(1 \mathrm{~mol} \%), \mathrm{PPh}_{3}(4 \mathrm{~mol} \%)$} & 6 & 65 & 6 & 29 \\
\hline 4 & {$[\mathrm{Ir}(\operatorname{cod}) \mathrm{Cl}]_{2}(5 \mathrm{~mol} \%), \mathrm{PPh}_{3}(20 \mathrm{~mol} \%)$} & 4 & 65 & 12 & 22 \\
\hline 5 & {$\left[\mathrm{Cp}^{*} \mathrm{IrCl}_{2}\right]_{2}(1 \mathrm{~mol} \%)$} & 4 & 65 & 9 & 40 \\
\hline 6 & {$\left[C p^{*} \mid r C l_{2}\right]_{2}(2$ mol\%) } & 4 & 65 & 0 & 45 \\
\hline 7 & {$\left[\mathrm{Cp}^{*} \mathrm{IrCl}_{2}\right]_{2}(5 \mathrm{~mol} \%)$} & 4 & 65 & 0 & 82 \\
\hline 8 & {$\left[\mathrm{Cp}^{*} \mathrm{RhCl}_{2}\right]_{2}(5 \mathrm{~mol} \%)$} & 4 & 65 & 8 & 2 \\
\hline 9 & {$\left[\mathrm{Cp}^{*} \mathrm{IrCl}_{2}\right]_{2}(5 \mathrm{~mol} \%)$} & 4 & 25 & 53 & 0 \\
\hline 10 & {$\left[\mathrm{Cp}^{*} \mathrm{IrCl}_{2}\right]_{2}(5 \mathrm{~mol} \%)$} & 4 & 45 & 55 & 11 \\
\hline $11^{\mathrm{b}}$ & {$\left[\mathrm{Cp}^{*} \mathrm{IrCl}_{2}\right]_{2}(5 \mathrm{~mol} \%)$} & 4 & 65 & 46 & 40 \\
\hline $12^{c}$ & {$\left[\mathrm{Cp}^{*} \mathrm{IrCl}_{2}\right]_{2}$ (5 mol\%) } & 4 & 65 & 0 & 75 \\
\hline $13^{\mathrm{d}, \mathrm{e}}$ & {$\left[C p^{*} \mid r C l_{2}\right]_{2}(5$ mol\%) } & 4 & 65 & 0 & 0 \\
\hline 14 & {$\left[\mathrm{Cp}^{*} \mathrm{IrCl}_{2}\right]_{2}$ (5 mol\%) } & - & 65 & 99 & 0 \\
\hline $15^{f}$ & - & 4 & 65 & 0 & 0 \\
\hline
\end{tabular}

${ }^{a}$ Isolated combined yields of $\mathbf{1}$ and $\mathbf{2 a}$. These products were inseparable by column chromatography and so the ratio $\mathbf{1} / \mathbf{2 a}$ was determined by ${ }^{1} \mathrm{H}$ NMR analysis of the purified mixture.

${ }^{\mathrm{b}}$ Concentration $=0.1 \mathrm{M}$.

c Concentration $=0.4 \mathrm{M}$.

${ }^{\mathrm{d}} \mathrm{O}_{2}$ atmosphere.

e Only compounds $\mathbf{3}$ and $\mathbf{4}$ were observed by ${ }^{1} \mathrm{H}$ NMR spectroscopy.

${ }^{\mathrm{f}}$ Compound $\mathbf{4}$ was the major product; no $\mathbf{1}, \mathbf{2 a}$, or $\mathbf{3}$ was observed by ${ }^{1} \mathrm{H}$ NMR spectroscopy. 
amount of $\mathrm{KOH}$ fixed at 4.0 equivalents, the catalyst/ligand loading was increased five-fold (entry 4); this did not, however, result in a larger quantity of $\mathbf{2 a}$ being formed. We then changed the precatalyst from $\operatorname{Ir}(\mathrm{I})$ to $\operatorname{Ir}(\mathrm{III})$, by employing $\left[\mathrm{Cp}^{*} \mathrm{IrCl}_{2}\right]_{2}$ (entry 5 ; $\mathrm{Cp}^{*}=\mathrm{n}^{5}$-pentamethylcyclopentadien$\mathrm{yl}$ ). The addition of more $\left[\mathrm{Cp}^{*} \mathrm{IrCl}_{2}\right]_{2}$ at the beginning of the reaction improved the yield of $2 \mathrm{a}$ considerably, with $5 \mathrm{~mol} \%$ $\left[\mathrm{Cp}^{*} \mathrm{IrCl}_{2}\right]_{2}$ providing clean formation of $\mathbf{2 a}$ in $82 \%$ yield (entry 7). Surprisingly, despite previous success, ${ }^{2 a}$ switching to $\mathrm{Rh}$ (III) resulted in extremely poor conversion into the desired C4-methylated phenol (entry 8). Further investigation with $\left[\mathrm{Cp}^{*} \mathrm{IrCl}_{2}\right]_{2}$ revealed that a temperature of $65^{\circ} \mathrm{C}$ was crucial for the desired reaction pathway to occur, with little 2a being formed at $25{ }^{\circ} \mathrm{C}$ and none being formed at $45^{\circ} \mathrm{C}$ (entries 9 and 10). Concentration was also shown to have an effect (entries 11 and 12), with $0.2 \mathrm{M}$ appropriate to ensure complete reaction and excellent yield.

With the optimal conditions in hand (entry 7), we also attempted to run the reaction under an atmosphere of oxygen. Previous research by our group ${ }^{2 a}$ and by others ${ }^{11}$ had shown oxygen to have a beneficial effect in hydrogen-borrowing chemistry when $\mathrm{MeOH}$ was used as the alkylating agent. However, in this instance a complex mixture was formed that contained neither unreacted 1 nor the desired product $\mathbf{2 a}$ (entry 13). Control experiments in which either $\mathrm{KOH}$ or $\left[\mathrm{Cp}^{*} \mathrm{IrCl}_{2}\right]_{2}$ was omitted resulted in only unreacted $\mathbf{1}$ (entry 14) or in complete consumption of the starting material to provide the dimerized product 4 (entry 15).

With the optimization studies complete, we next chose to investigate the scope of the alcohols that could be used in this process (Scheme 2). During this investigation, it quickly became apparent that higher temperatures were required to obtain the desired alkylated products, as unreacted 2,6di-tert-butylphenol (1), dimer $\mathbf{4}$, and several other unidentified byproducts were obtained when the reaction was performed at $65{ }^{\circ} \mathrm{C}$ (not shown). We speculate that the additional steric bulk of these alcohols hinders the addition of the metal hydride, thereby making the reduction step difficult and preventing efficient formation of the desired alkylated product.

Pleasingly, adjustment of the reaction temperature (as shown in Scheme 2 for each alcohol) provided a wide range of C4-alkylated products. Both linear and branched primary alcohols were readily processed by using this method, forming the desired compounds in good yields (Scheme 2; 5a-8a). Such materials would be difficult to make by conventional Friedel-Crafts-type alkylation processes, which instead involve rearrangement of the putative unstable primary cation to a more favorable secondary cation to yield the corresponding branched alkylated product. ${ }^{12}$ Cyclopropylmethanol could also be employed under the reaction conditions to provide phenol 9a, but temperatures exceeding $85^{\circ} \mathrm{C}$ resulted in competitive ring opening to give phenol $\mathbf{5 a}$ in appreciable amounts. Several benzylic and hetero-
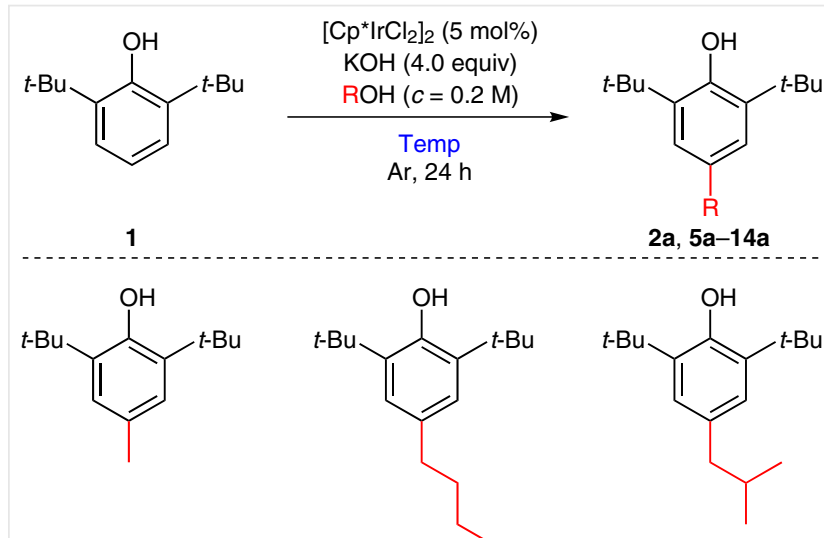

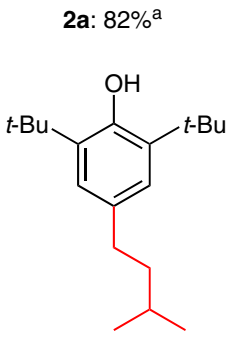

7a: $64 \%^{d}$<smiles>CC(C)(C)c1cc(CC2CCCO2)cc(C(C)(C)C)c1O</smiles>

10a: $72 \%{ }^{d}$

$$
\text { 5a: } 71 \% c
$$<smiles>CCOCCc1cc(C(C)(C)C)c(O)c(C(C)(C)C)c1</smiles>

8a: $64 \%^{c}$<smiles>CC(C)(C)c1cc(Cc2ccccc2)cc(C(C)(C)C)c1O</smiles>

11a: $84 \%^{d}$<smiles>CC(C)(C)c1cc(CC2CC2)cc(C(C)(C)C)c1O</smiles>

9a: $40 \%^{\mathrm{b}}$<smiles>CC(C)(C)c1cc(Cc2ccco2)cc(C(C)(C)C)c1O</smiles>

12a: $80 \%$ d<smiles>CC(C)(C)c1cc(Cc2cccs2)cc(C(C)(C)C)c1O</smiles>

13a: $66 \%$ d<smiles>CC(C)(C)c1cc(Cc2cccnc2)cc(C(C)(C)C)c1O</smiles>

14a: $93 \%$
Reaction performed at: ${ }^{a} 65^{\circ} \mathrm{C} ;{ }^{b} 85^{\circ} \mathrm{C} ;{ }^{c} 105^{\circ} \mathrm{C} ;{ }^{d} 125^{\circ} \mathrm{C}$

Scheme 2 Alcohol scope of the iridium-catalyzed C4-alkylation of 2,6di-tert-butylphenol. The reactions were performed by using $0.30 \mathrm{mmol}$ of 2,6-di-tert-butylphenol.

cyclic alcohols were also shown to be viable alkylating agents, giving rise to products $\mathbf{1 0 a}-\mathbf{1 4 a}$ in good to excellent isolated yields (66-93\%). ${ }^{13}$

Next, we attempted to remove the tert-butyl groups by means of a retro-Friedel-Crafts reaction. A selection of C4alkylated products were treated with $\mathrm{AlCl}_{3}$ in the presence of toluene as a tert-butyl acceptor (Scheme 3). ${ }^{14}$ Pleasingly, this process proceeded rapidly to deliver the corresponding 
para-substituted phenols $\mathbf{2 b}, \mathbf{7 b}, \mathbf{1 0 b}$, and $\mathbf{1 4 b}$ in good to excellent yields, thereby permitting subsequent synthetic manipulation at the ortho-positions.<smiles>[R]c1cc(C(C)(C)C)c(O)c(C(C)(C)C)c1</smiles>

2a: $\mathrm{R}=\mathrm{CH}_{3}$

7a: $\mathrm{R}=\mathrm{CH}_{2} \mathrm{CH}_{2} \mathrm{CH}\left(\mathrm{CH}_{3}\right)_{2}$

10a: $\mathrm{R}=\mathrm{CH}_{2}(2-\mathrm{THF})$

14a: $\mathrm{R}=\mathrm{CH}_{2}(3-\mathrm{Pyr})$

Scheme 3 Removal of the tert-butyl groups under retro-Friedel-Crafts conditions

With respect to the mechanism of the C4-alkylation process, we assume that the reaction proceeds by initial oxidation of the primary alcohol to the corresponding aldehyde in situ to generate an iridium hydride ${ }^{15}$ species. Deprotonation of the phenol then provides anion 15, which reacts through the $\pi$-system to form the corresponding C4hydroxymethylated species. Elimination of hydroxide produces p-quinone methide $\mathbf{1 6}$ as a fleeting intermediate, which might be subsequently reduced by the iridium hydride to give the desired alkylated product (Scheme 4).

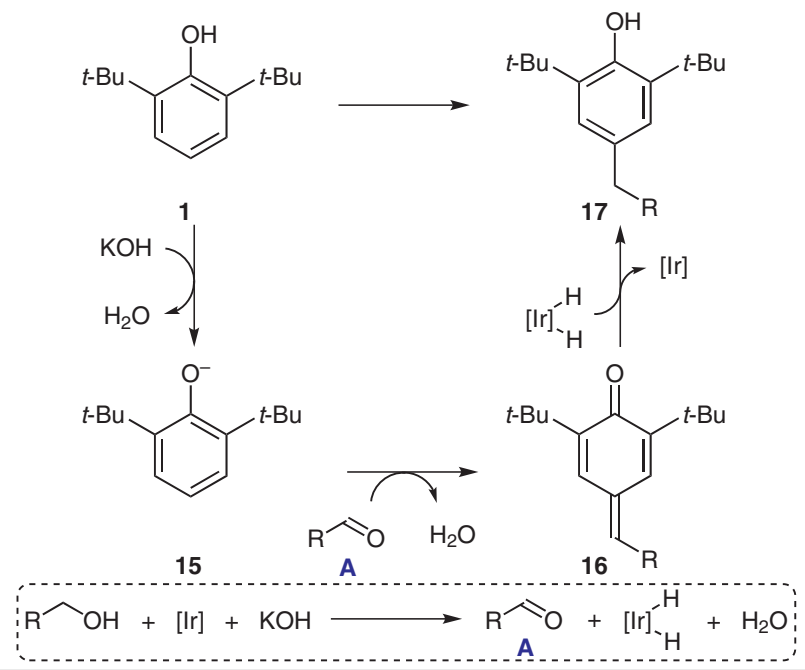

Scheme 4 Proposed mechanism for the C4-alkylation reaction; the iridium dihydride is shown for clarity ${ }^{15}$

In conclusion, we have shown that 2,6-di-tert-butylphenol can be straightforwardly alkylated at the C4-position by using a variety of alcohols. The tert-butyl groups can subsequently be removed under retro-Friedel-Crafts conditions to provide additional phenol products. Examinations of further applications of hydrogen-borrowing chemistry and its relevance to phenols are currently underway in our laboratory.
Reactions performed according to General Procedure A were run in glassware that was not flame-dried. Reactions performed according to General Procedure B were run under argon in anhydrous conditions in flame-dried glassware. Benzyl alcohol was purchased from Avocado, and used as supplied. All other reagents were commercially sourced from Sigma-Aldrich, Alfa Aesar, or Fluorochem and were purchased in the highest available purity. TLC was performed on precoated aluminum-backed Merck TLC Silica Gel $60 \mathrm{~F}_{254}$ plates that were visualized by UV irradiation $(\lambda=254 \mathrm{~nm})$ and/or by staining with $\mathrm{KMnO}_{4}$ or vanillin solutions. Flash column chromatography was performed with Merck Geduran ${ }^{\circledR}$ Si $60(0.040-0.063 \mathrm{~mm})$ silica gel with the indicated solvent systems. All solvents used for chromatographic purification were of HPLC grade or equivalent and were supplied by Sigma-Aldrich. Fourier-transform IR spectra were recorded on evaporated films on a Bruker Tensor 27 spectrometer equipped with a Pike Miracle attenuated total reflectance (ATR) sampling accessory. All NMR spectra were recorded on either a Bruker AVIII HD 400 spectrometer equipped with a $5 \mathrm{~mm} z$-gradient BBFO probe or an AVIII HD 500 spectrometer equipped with a $5 \mathrm{~mm}$ double-resonance $\mathrm{BBF} / \mathrm{H}$ SMART probe, with the deuterated solvent acting as an internal deuterium lock. ${ }^{1} \mathrm{H}$ NMR spectra were recorded at $400 \mathrm{MHz}$, and ${ }^{13} \mathrm{C}$ NMR spectra were recorded at $101 \mathrm{MHz}$ with broadband decoupling. Residual protic solvent signal acted as an internal reference for ${ }^{1} \mathrm{H}$ NMR, and the deuterated solvent carbon signal acted as an internal reference for ${ }^{13} \mathrm{C}$ NMR $\left(\mathrm{CDCl}_{3}:{ }^{1} \mathrm{H}\right.$ NMR, $\delta=7.26 \mathrm{ppm} ;{ }^{13} \mathrm{C}$ NMR, $\delta=$ $77.16 \mathrm{ppm}$; DMSO- $d_{6}:{ }^{1} \mathrm{H}$ NMR, $\delta=2.50 \mathrm{ppm} ;{ }^{13} \mathrm{C}$ NMR, $\delta=39.50$ $\mathrm{ppm})$. Chemical shifts are quoted to the nearest $0.01 \mathrm{ppm}$ for ${ }^{1} \mathrm{H}$ NMR or $0.1 \mathrm{ppm}$ for ${ }^{13} \mathrm{C}$ NMR. Coupling constants are quoted to the nearest $0.1 \mathrm{~Hz}$. High-resolution mass spectra were recorded on a Thermo Exactive orbitrap spectrometer equipped with a Waters Equity LC system with a flow rate of $0.2 \mathrm{~mL} / \mathrm{min}$ for $\mathrm{H}_{2} \mathrm{O}-\mathrm{MeOH}-\mathrm{HCO}_{2} \mathrm{H}$ (10:89.9:0.1) as eluent. The system uses a heated electrospray ionization (HESI-II) probe for $\mathrm{ESI}^{-}$and has a resolution of $50000 \mathrm{FWHM}$ under conditions for maximum sensitivity, with an accuracy of better than $5 \mathrm{ppm}$ for $24 \mathrm{~h}$ following external calibration on the day of analysis. The reported mass is that containing the most abundant isotopes, with each value given to four decimal places; all were within $5 \mathrm{ppm}$ of the calculated mass. Melting points were obtained by using a Leica VMTG heated-stage microscope equipped with a Testo 720 thermometer and are uncorrected.

\section{4-Alkyl-2,6-di-tert-butylphenols 2a, 5a-14a; General Procedure A}

A 2-5 mL Biotage ${ }^{\circledR}$ microwave vial equipped with a stirrer bar was successively charged with 2,6-di-tert-butylphenol ( $1 ; 1.0$ equiv), the appropriate alcohol $(0.2 \mathrm{M}),\left[\mathrm{Cp}^{*} \mathrm{IrCl}_{2}\right]_{2}$ (5 mol\%), and $\mathrm{KOH}$ (4.0 equiv) in the open atmosphere. The vessel was sealed with a microwave vial cap equipped with a Reseal septum and then purged with argon for 5 mins by using a balloon. The vial, complete with argon balloon, was heated to the required temperature in a preheated oil bath for $24 \mathrm{~h}$. The mixture was cooled to r.t., filtered through a silica plug (with elution by the appropriate eluent system to remove inorganics and excess alcohol), and concentrated in vacuo. The product was purified by column chromatography.

\section{4-Alkylphenols 2b, 7b, 10b, and 14b; General Procedure B}

To a solution of the appropriate phenol (1.0 equiv) in toluene $(0.02 \mathrm{M})$ at r.t. was added a solution of $\mathrm{AlCl}_{3}$ (6.0 or 9.0 equiv) in $\mathrm{MeNO}_{2}$ $(2.25 \mathrm{M})$ in one portion. The mixture was immediately heated to $60{ }^{\circ} \mathrm{C}$ by using a preheated oil bath and maintained at this temperature for $5 \mathrm{~min}$. The mixture was subsequently cooled and poured into a separatory funnel containing ice and $\mathrm{Et}_{2} \mathrm{O}$ (1:1). The layers were 
separated and the aqueous layer was extracted with $\mathrm{Et}_{2} \mathrm{O}(\times 3)$. The combined organics were dried $\left(\mathrm{MgSO}_{4}\right)$, filtered, and concentrated in vacuo. The product was purified by column chromatography.

\section{2,6-Di-tert-butyl-4-methylphenol (2a)}

2,6-Di-tert-butylphenol (1; $62.0 \mathrm{mg}, 0.30 \mathrm{mmol}),\left[\mathrm{Cp}^{*} \mathrm{IrCl}_{2}\right]_{2}(12.0 \mathrm{mg}$, $0.015 \mathrm{mmol}), \mathrm{KOH}(67.3 \mathrm{mg}, 1.20 \mathrm{mmol})$, and $\mathrm{MeOH}(1.5 \mathrm{~mL})$ were subjected to General Procedure A at $65^{\circ} \mathrm{C}$. After $24 \mathrm{~h}$, the mixture was cooled and filtered through a plug of silica gel (eluting with pentane). Purification by column chromatography (silica gel, eluent load, pentane) afforded the title compound $\mathbf{2 a}(54.1 \mathrm{mg}, 82 \%)$ as a colorless solid; $R_{f}=0.63$ (pentane-Et ${ }_{2} \mathrm{O}, 98: 2$ ) [UV, $\mathrm{KMnO}_{4}$ ].

${ }^{1} \mathrm{H}$ NMR $\left(400 \mathrm{MHz}, \mathrm{CDCl}_{3}\right): \delta=6.99(\mathrm{~s}, 2 \mathrm{H}), 5.02(\mathrm{~s}, 1 \mathrm{H}), 2.28(\mathrm{~s}, 3 \mathrm{H})$, $1.44(\mathrm{~s}, 18 \mathrm{H})$.

${ }^{13} \mathrm{C}$ NMR $\left(101 \mathrm{MHz}, \mathrm{CDCl}_{3}\right): \delta=151.7,135.9,128.4,125.7,34.4,30.5$, 21.3.

\section{4-Butyl-2,6-di-tert-butylphenol (5a)}

2,6-Di-tert-butylphenol (62.0 mg, $0.30 \mathrm{mmol}$ ), [Cp* $\left.\mathrm{CrCl}_{2}\right]_{2}(12.0 \mathrm{mg}$, $0.015 \mathrm{mmol}), \mathrm{KOH}(67.3 \mathrm{mg}, 1.20 \mathrm{mmol})$, and $\mathrm{BuOH}(1.5 \mathrm{~mL})$ were subjected to General Procedure A at $105^{\circ} \mathrm{C}$. After $24 \mathrm{~h}$, the mixture was cooled and filtered through a plug of silica gel (eluting with pentane). Purification by column chromatography (silica gel, eluent load, pentane) afforded a colorless oil; yield: $56.0 \mathrm{mg}(71 \%) ; R_{f}=0.29$ (pentane) [UV, $\left.\mathrm{KMnO}_{4}\right]$.

IR (film): 3649, 2955, 2928, 2914, 2873, 2856, 1484, 1467, 1433, 1392, 1361, 1315, 1249, 1231, 1212, 1196, 1157, 1121, 1024, $933 \mathrm{~cm}^{-1}$.

${ }^{1} \mathrm{H}$ NMR $\left(400 \mathrm{MHz}, \mathrm{CDCl}_{3}\right): \delta=6.98(\mathrm{~s}, 2 \mathrm{H}), 5.02(\mathrm{~s}, 1 \mathrm{H}), 2.52(\mathrm{dd}, J=$ 8.0, 7.9 Hz, $2 \mathrm{H}), 1.62-1.52(\mathrm{~m}, 2 \mathrm{H}), 1.44(\mathrm{~s}, 18 \mathrm{H}), 1.39$ (app. sext, $J=$ $7.2 \mathrm{~Hz}, 2 \mathrm{H}), 0.94(\mathrm{t}, J=7.3 \mathrm{~Hz}, 3 \mathrm{H})$.

${ }^{13} \mathrm{C}$ NMR $\left(101 \mathrm{MHz}, \mathrm{CDCl}_{3}\right): \delta=151.8,135.7,133.7,125.0,35.9,34.4$, $34.4,30.5,22.9,14.2$.

HRMS (ESI): $m / z$ [M - H] $]^{-}$calcd for $\mathrm{C}_{18} \mathrm{H}_{29} \mathrm{O}_{1}$ : 261.2224; found: 261.2224 .

\section{4-Isobutyl-2,6-di-tert-butylphenol (6a) ${ }^{16}$}

2,6-Di-tert-butylphenol (62.0 mg, $0.30 \mathrm{mmol}),\left[\mathrm{Cp}^{*} \mathrm{IrCl}_{2}\right]_{2}(12.0 \mathrm{mg}$, $0.015 \mathrm{mmol}), \mathrm{KOH}$ (67.3 mg, $1.20 \mathrm{mmol}$ ), and 2-methylpropan-1-ol $(1.5 \mathrm{~mL})$ were subjected to General Procedure $\mathrm{A}$ at $105^{\circ} \mathrm{C}$. After $24 \mathrm{~h}$, the mixture was cooled and filtered through a plug of silica gel (eluting with pentane). Purification by column chromatography (silica gel, eluent load, pentane) afforded a colorless oil; yield: $32.8 \mathrm{mg}$ (42\%); $R_{f}=0.29$ (pentane) [UV, $\left.\mathrm{KMnO}_{4}\right]$.

IR (film): 3649, 3003, 2952, 2911, 2868, 2844, 1484, 1467, 1434, $1394,1385,1362,1315,1271,1250,1233,1214,1196,1157,1120$, $1089,1024,932 \mathrm{~cm}^{-1}$.

${ }^{1} \mathrm{H}$ NMR $\left(400 \mathrm{MHz}, \mathrm{CDCl}_{3}\right): \delta=6.94(\mathrm{~s}, 2 \mathrm{H}), 5.02(\mathrm{~s}, 1 \mathrm{H}), 2.39(\mathrm{~d}, J=$ $7.1 \mathrm{~Hz}, 2 \mathrm{H}$ ), 1.80 (app. nonet, $J=6.7 \mathrm{~Hz}, 1 \mathrm{H}$ ), 1.45 (s, $18 \mathrm{H}$ ), 0.92 (d, $J=6.7 \mathrm{~Hz}, 6 \mathrm{H})$.

${ }^{13} \mathrm{C}$ NMR $\left(101 \mathrm{MHz}, \mathrm{CDCl}_{3}\right): \delta=151.8,135.5,132.4,125.7,45.6,34.4$, 30.6, 30.6, 22.7.

HRMS (ESI): $m / z$ [M - H] $]^{-}$calcd for $\mathrm{C}_{18} \mathrm{H}_{29} \mathrm{O}_{1}$ : 261.2224; found: 261.2223.

\section{2,6-Di-tert-butyl-4-isopentylphenol (7a)}

2,6-Di-tert-butylphenol $(62.0 \mathrm{mg}, 0.30 \mathrm{mmol}),\left[\mathrm{Cp}^{*} \mathrm{IrCl}_{2}\right]_{2}(12.0 \mathrm{mg}$, $0.015 \mathrm{mmol}), \mathrm{KOH}(67.3 \mathrm{mg}, 1.20 \mathrm{mmol})$, and 3-methylbutan-1-ol $(1.5 \mathrm{~mL})$ were subjected to General Procedure A at $125^{\circ} \mathrm{C}$. After $24 \mathrm{~h}$, the mixture was cooled and filtered through a plug of silica gel (eluting with pentane). Purification by column chromatography (silica gel, eluent load, pentane) afforded a colorless oil; yield: $53.4 \mathrm{mg} \mathrm{(64 \% );}$ $R_{f}=0.38$ (pentane) [UV, $\mathrm{KMnO}_{4}$ ].

IR (film): 3649, 3003, 2954, 2912, 2870, 1484, 1468, 1434, 1388, 1363, 1314, 1269, 1250, 1231, 1212, 1197, 1157, 1121, 1095, 1025, $932 \mathrm{~cm}^{-1}$.

${ }^{1} \mathrm{H}$ NMR (400 MHz, $\mathrm{CDCl}_{3}$ ): $\delta=7.00(\mathrm{~s}, 2 \mathrm{H}), 5.04(\mathrm{~s}, 1 \mathrm{H}), 2.57-2.51$ (m, $2 \mathrm{H}), 1.63$ (app. nonet, $J=6.5 \mathrm{~Hz}, 1 \mathrm{H}), 1.54-1.46(\mathrm{~m}, 2 \mathrm{H}), 1.46(\mathrm{~s}$, $18 \mathrm{H}), 0.97(\mathrm{~d}, J=6.6 \mathrm{~Hz}, 6 \mathrm{H})$.

${ }^{13} \mathrm{C}$ NMR $\left(101 \mathrm{MHz}, \mathrm{CDCl}_{3}\right): \delta=151.7,138.8,133.8,124.9,41.5,34.5$, 34.0, 30.5, 28.2, 22.8

HRMS (ESI): $m / z\left[M-\mathrm{H}^{-}\right.$calcd for $\mathrm{C}_{19} \mathrm{H}_{31} \mathrm{O}_{1}: 275.2380$; found: 275.2380

\section{2,6-Di-tert-butyl-4-(2-ethoxyethyl)phenol (8a)}

2,6-Di-tert-butylphenol (62.0 mg, $0.30 \mathrm{mmol}),\left[\mathrm{Cp}^{*} \mathrm{IrCl}_{2}\right]_{2}(12.0 \mathrm{mg}$, $0.015 \mathrm{mmol}), \mathrm{KOH}(67.3 \mathrm{mg}, 1.20 \mathrm{mmol})$, and 2-ethoxyethanol $(1.5 \mathrm{~mL})$ were subjected to General Procedure A at $105^{\circ} \mathrm{C}$. After $24 \mathrm{~h}$, the mixture was cooled and filtered through a plug of silica gel [eluting with pentane- $\left.\mathrm{Et}_{2} \mathrm{O}(98: 2)\right]$. Purification by column chromatography [silica gel, eluent load, pentane- $\mathrm{Et}_{2} \mathrm{O}(98: 2)$ ] afforded a colorless oil; yield: $53.7 \mathrm{mg}$ (64\%); $R_{f}=0.40$ (pentane- $\mathrm{Et}_{2} \mathrm{O}, 95: 5$ ) [UV, $\mathrm{KMnO}_{4}$ ]. IR (film): 3646, 3003, 2972, 2954, 2913, 2865, 1485, 1434, 1392, 1375, 1359, 1316, 1272, 1250, 1233, 1212, 1197, 1157, 1131, 1107, $1048,1025,994 \mathrm{~cm}^{-1}$.

${ }^{1} \mathrm{H} \mathrm{NMR}\left(400 \mathrm{MHz}, \mathrm{CDCl}_{3}\right): \delta=7.03(\mathrm{~s}, 2 \mathrm{H}), 5.07(\mathrm{~s}, 1 \mathrm{H}), 3.61(\mathrm{t}, J=$ $7.5 \mathrm{~Hz}, 2 \mathrm{H}), 3.53(\mathrm{q}, J=7.0 \mathrm{~Hz}, 2 \mathrm{H}), 2.82(\mathrm{t}, J=7.5 \mathrm{~Hz}, 2 \mathrm{H}), 1.44(\mathrm{~s}, 18$ $\mathrm{H}), 1.23(\mathrm{t}, J=7.0 \mathrm{~Hz}, 3 \mathrm{H})$.

${ }^{13} \mathrm{C}$ NMR $\left(101 \mathrm{MHz}, \mathrm{CDCl}_{3}\right): \delta=152.3,135.8,129.5,125.6,72.3,66.3$, $36.4,34.4,30.5,15.4$.

HRMS (ESI): $m / z$ [M $-\mathrm{H}]^{-}$calcd for $\mathrm{C}_{18} \mathrm{H}_{29} \mathrm{O}_{2}$ : 277.2173; found: 277.2172.

\section{2,6-Di-tert-butyl-4-(cyclopropylmethyl)phenol (9a)}

2,6-Di-tert-butylphenol (62.0 mg, $0.30 \mathrm{mmol}),\left[\mathrm{Cp}^{*} \mathrm{IrCl}_{2}\right]_{2}(12.0 \mathrm{mg}$, $0.015 \mathrm{mmol}), \mathrm{KOH}(67.3 \mathrm{mg}, 1.20 \mathrm{mmol})$, and cyclopropylmethanol $(1.5 \mathrm{~mL})$ were subjected to General Procedure A at $85^{\circ} \mathrm{C}$. After $24 \mathrm{~h}$, the mixture was cooled and filtered through a plug of silica gel (eluting with pentane). Purification by column chromatography (silica gel, eluent load, pentane) afforded a colorless solid; yield: $31.0 \mathrm{mg}(40 \%)$; mp 40-42 ${ }^{\circ} \mathrm{C} ; R_{f}=0.29$ (pentane) [UV, $\mathrm{KMnO}_{4}$ ].

IR (film): 3646, 3076, 3002, 2954, 2913, 2872, 1484, 1468, 1434, 1392, 1361, 1317, 1305, 1250, 1231, 1211, 1196, 1157, 1120, 1044, $1015,981 \mathrm{~cm}^{-1}$.

${ }^{1} \mathrm{H} \mathrm{NMR}\left(400 \mathrm{MHz}, \mathrm{CDCl}_{3}\right): \delta=7.08(\mathrm{~s}, 2 \mathrm{H}), 5.05(\mathrm{~s}, 1 \mathrm{H}), 2.47$ (d, $J=$ $6.8 \mathrm{~Hz}, 2 \mathrm{H}), 1.44(\mathrm{~s}, 18 \mathrm{H}), 0.97$ (ttt, $J=8.0,6.9,5.0 \mathrm{~Hz}, 1 \mathrm{H}), 0.55-0.49$ ( $\mathrm{m}, 2 \mathrm{H}), 0.20-0.17(\mathrm{~m}, 2 \mathrm{H})$.

${ }^{13} \mathrm{C}$ NMR $\left(101 \mathrm{MHz}, \mathrm{CDCl}_{3}\right): \delta=152.0,135.7,132.8,125.0,40.4,34.4$, 30.5, 12.2, 4.8.

HRMS (ESI): $m / z$ [M - H] $]^{-}$calcd for $\mathrm{C}_{18} \mathrm{H}_{27} \mathrm{O}_{1}$ : 259.2067; found: 259.2066

\section{2,6-Di-tert-butyl-4-(tetrahydrofuran-2-ylmethyl)phenol (10a)}

2,6-Di-tert-butylphenol (62.0 mg, $0.30 \mathrm{mmol}),\left[\mathrm{Cp}^{*} \mathrm{IrCl}_{2}\right]_{2}(12.0 \mathrm{mg}$, $0.015 \mathrm{mmol}), \mathrm{KOH}(67.3 \mathrm{mg}, 1.20 \mathrm{mmol})$, and tetrahydrofurfuryl alcohol $(1.5 \mathrm{~mL})$ were subjected to General Procedure A at $125^{\circ} \mathrm{C}$. After $24 \mathrm{~h}$, the mixture was cooled and filtered through a plug of silica gel 
[eluting with pentane- $\mathrm{Et}_{2} \mathrm{O}$ (98:2)]. Purification by column chromatography [silica gel, eluent load, pentane- $\mathrm{Et}_{2} \mathrm{O}(98: 2)$ ] afforded a colorless solid; yield: $62.5 \mathrm{mg}(72 \%) ; \mathrm{mp} 74-76{ }^{\circ} \mathrm{C} ; R_{f}=0.26$ (pentane$\left.\mathrm{Et}_{2} \mathrm{O}, 95: 5\right)$ [UV, $\left.\mathrm{KMnO}_{4}\right]$.

This procedure was also scaled up five-fold ( $1.50 \mathrm{mmol}$ of 2,6-di-tertbutylphenol) to give 10a in comparable yield [ $321 \mathrm{mg}$ (74\%)].

IR (film): 3637, 2975, 2955, 2917, 2873, 2855, 1484, 1432, 1399, 1390, 1367, 1359, 1305, 1271, 1235, 1213, 1197, 1164, 1139, 1120, $1060,1027,968 \mathrm{~cm}^{-1}$.

${ }^{1} \mathrm{H}$ NMR (400 MHz, $\mathrm{CDCl}_{3}$ ): $\delta=7.01(\mathrm{~s}, 2 \mathrm{H}$ ), 5.05 (s, $1 \mathrm{H}$ ), 4.03 (app. quint, $J=6.7 \mathrm{~Hz}, 1 \mathrm{H}$ ), 3.90 (ddd, $J=8.3,7.2,6.1 \mathrm{~Hz}, 1 \mathrm{H}$ ), 3.74 (td, $J=$ 7.9, $6.2 \mathrm{~Hz}, 1 \mathrm{H}$ ), 2.85 (dd, $J=13.6,6.1 \mathrm{~Hz}, 1 \mathrm{H}$ ), 2.65 (dd, $J=13.6$, $6.8 \mathrm{~Hz}, 1 \mathrm{H}), 1.99-1.78$ (m, $3 \mathrm{H}), 1.62-1.51(\mathrm{~m}, 1 \mathrm{H}), 1.43(\mathrm{~s}, 18 \mathrm{H})$.

${ }^{13} \mathrm{C} \mathrm{NMR}\left(101 \mathrm{MHz}, \mathrm{CDCl}_{3}\right): \delta=152.3,135.7,129.6,125.8,80.6,68.0$, $42.1,34.4,31.2,30.5,25.7$.

HRMS (ESI): $m / z$ [M - H] $]^{-}$calcd for $\mathrm{C}_{19} \mathrm{H}_{29} \mathrm{O}_{2}$ : 289.2173; found: 289.2172 .

\section{4-Benzyl-2,6-di-tert-butylphenol (11a) ${ }^{17}$}

2,6-Di-tert-butylphenol (62.0 mg, $0.30 \mathrm{mmol}),\left[\mathrm{Cp}^{*} \mathrm{IrCl}_{2}\right]_{2}(12.0 \mathrm{mg}$, $0.015 \mathrm{mmol}), \mathrm{KOH}(67.3 \mathrm{mg}, 1.20 \mathrm{mmol})$, and $\mathrm{BnOH}(1.5 \mathrm{~mL})$ were subjected to General Procedure A at $125^{\circ} \mathrm{C}$. After $24 \mathrm{~h}$, the mixture was cooled and filtered through a plug of silica gel (eluting with pentane). Purification by column chromatography (silica gel, eluent load, pentane) afforded a colorless solid; yield: $75.1 \mathrm{mg}$ (84\%); $\mathrm{mp} \mathrm{47-}$ $49^{\circ} \mathrm{C} ; R_{f}=0.29$ (pentane) [UV, $\mathrm{KMnO}_{4}$ ].

IR (film): 3623, 2960, 2954, 2912, 2872, 1495, 1482, 1454, 1431, 1392, 1363, 1308, 1246, 1232, 1212, 1197, 1176, 1143, 1120, 1076, $1027,935 \mathrm{~cm}^{-1}$.

${ }^{1} \mathrm{H}$ NMR (400 MHz, $\left.\mathrm{CDCl}_{3}\right): \delta=7.36-7.30(\mathrm{~m}, 2 \mathrm{H}), 7.27-7.20(\mathrm{~m}, 3 \mathrm{H})$, 7.04 (s, $2 \mathrm{H}), 5.11$ (s, $1 \mathrm{H}), 3.95$ (s, $2 \mathrm{H}), 1.46$ (s, $18 \mathrm{H})$.

${ }^{13} \mathrm{C}$ NMR (101 MHz, $\left.\mathrm{CDCl}_{3}\right): \delta=152.2,141.9,135.9,131.7,129.0$, $128.5,125.9,125.6,42.0,34.4,30.5$.

HRMS (ESI): $m / z[M-H]^{-}$calcd for $\mathrm{C}_{21} \mathrm{H}_{27} \mathrm{O}_{1}$ : 295.2067; found: 295.2067.

\section{2,6-Di-tert-butyl-4-(2-furylmethyl)phenol (12a)}

2,6-Di-tert-butylphenol (62.0 mg, $0.30 \mathrm{mmol}),\left[\mathrm{Cp}^{*} \mathrm{IrCl}_{2}\right]_{2}(12.0 \mathrm{mg}$, $0.015 \mathrm{mmol}), \mathrm{KOH}(67.3 \mathrm{mg}, 1.20 \mathrm{mmol})$, and furfuryl alcohol $(1.5 \mathrm{~mL})$ were subjected to General Procedure A at $125^{\circ} \mathrm{C}$. After $24 \mathrm{~h}$, the mixture was cooled and filtered through a plug of silica gel [eluting with pentane- $\mathrm{Et}_{2} \mathrm{O}$ (99:1)]. Purification by column chromatography [silica gel, eluent load, pentane- $\mathrm{Et}_{2} \mathrm{O}(100: 0$ to $99: 1)$ ] afforded a colorless solid; yield: $68.5 \mathrm{mg}(80 \%) ; \mathrm{mp} 72-74{ }^{\circ} \mathrm{C} ; R_{f}=0.44$ (pentane) [UV, $\mathrm{KMnO}_{4}$ ].

IR (film): 3639, 2976, 2952, 2915, 2876, 2862, 1509, 1471, 1432 , $1401,1390,1360,1307,1272,1236,1213,1197,1169,1138,1120$, $1068,1028,1004,938 \mathrm{~cm}^{-1}$.

${ }^{1} \mathrm{H}$ NMR (400 MHz, $\left.\mathrm{CDCl}_{3}\right): \delta=7.34(\mathrm{dd}, J=1.8,0.8 \mathrm{~Hz}, 1 \mathrm{H}), 7.04(\mathrm{~s}, 2$ $\mathrm{H}), 6.30(\mathrm{dd}, J=3.1,1.9 \mathrm{~Hz}, 1 \mathrm{H}), 6.00(\mathrm{dd}, J=3.1,0.8 \mathrm{~Hz}, 1 \mathrm{H}), 5.10(\mathrm{~s}$, $1 \mathrm{H}), 3.90(\mathrm{~s}, 2 \mathrm{H}), 1.43(\mathrm{~s}, 18 \mathrm{H})$.

${ }^{13} \mathrm{C}$ NMR $\left(101 \mathrm{MHz}, \mathrm{CDCl}_{3}\right): \delta=155.5,152.5,141.4,136.0,128.8$, $125.4,110.3,106.1,34.4,34.4,30.4$.

HRMS (ESI): $m / z[\mathrm{M}-\mathrm{H}]^{-}$calcd for $\mathrm{C}_{19} \mathrm{H}_{25} \mathrm{O}_{2}$ : 285.1860; found: 285.1859 .

\section{2,6-Di-tert-butyl-4-(2-thienylmethyl)phenol (13a)}

2,6-Di-tert-butylphenol (62.0 mg, $0.30 \mathrm{mmol}),\left[\mathrm{Cp}^{*} \mathrm{IrCl}_{2}\right]_{2}(12.0 \mathrm{mg}$, $0.015 \mathrm{mmol}), \mathrm{KOH}(67.3 \mathrm{mg}, 1.20 \mathrm{mmol})$, and 2-thienylmethanol $(1.5 \mathrm{~mL})$ were subjected to General Procedure A at $125^{\circ} \mathrm{C}$. After $24 \mathrm{~h}$, the mixture was cooled and filtered through a plug of silica gel [eluting with pentane- $\mathrm{Et}_{2} \mathrm{O}$ (100:0 to $98: 2$ to $\left.\left.95: 5\right)\right]$. Purification by column chromatography [silica gel, eluent load, pentane- $\mathrm{Et}_{2} \mathrm{O}$ (99:1)] afforded a yellow solid; yield: $60.0 \mathrm{mg}(66 \%) ; \mathrm{mp} 39-41{ }^{\circ} \mathrm{C} ; R_{f}=0.50$ (pentane- $\mathrm{Et}_{2} \mathrm{O}, 98: 2$ ) [UV, $\mathrm{KMnO}_{4}$ ].

IR (film): 3628, 3000, 2967, 2953, 2912, 2870, 1484, 1430, 1391, $1360,1314,1271,1249,1229,1211,1195,1183,1146,1121,1104$, $1073,1036,1023,932 \mathrm{~cm}^{-1}$.

${ }^{1} \mathrm{H}$ NMR ( $400 \mathrm{MHz}, \mathrm{CDCl}_{3}$ ): $\delta=7.15$ (dd, $\left.J=5.1,1.2 \mathrm{~Hz}, 1 \mathrm{H}\right), 7.08(\mathrm{~s}, 2$ $\mathrm{H}), 6.94(\mathrm{dd}, J=5.1,3.4 \mathrm{~Hz}, 1 \mathrm{H}), 6.81(\mathrm{dd}, J=3.4,1.1 \mathrm{~Hz}, 1 \mathrm{H}), 5.12(\mathrm{~s}$, $1 \mathrm{H}), 4.10(\mathrm{~s}, 2 \mathrm{H}), 1.45(\mathrm{~s}, 18 \mathrm{H})$.

${ }^{13} \mathrm{C}$ NMR $\left(101 \mathrm{MHz}, \mathrm{CDCl}_{3}\right): \delta=152.4,145.2,136.0,131.0,126.9$, 125.3, 124.9, 123.7, 36.0, 34.5, 30.4.

HRMS (ESI): $m / z$ [M - H] $]^{-}$calcd for $\mathrm{C}_{19} \mathrm{H}_{25} \mathrm{O}_{1} \mathrm{~S}_{1}: 301.1632$; found: 301.1631 .

\section{2,6-Di-tert-butyl-4-(pyridin-3-ylmethyl)phenol (14a)}

2,6-Di-tert-butylphenol (62.0 mg, $0.30 \mathrm{mmol}),\left[\mathrm{Cp}^{*} \mathrm{IrCl}_{2}\right]_{2}(12.0 \mathrm{mg}$, $0.015 \mathrm{mmol}), \mathrm{KOH}(67.3 \mathrm{mg}, 1.20 \mathrm{mmol})$, and pyridin-3-ylmethanol $(1.5 \mathrm{~mL})$ were subjected to General Procedure A at $105^{\circ} \mathrm{C}$. After $24 \mathrm{~h}$, the mixture was cooled and filtered through a plug of silica gel [eluting with pentane- $\left.\mathrm{Et}_{2} \mathrm{O}(50: 50)\right]$. Purification by column chromatography [silica gel, eluent $/ \mathrm{CH}_{2} \mathrm{Cl}_{2}$ load, pentane- $\mathrm{Et}_{2} \mathrm{O}(50: 50)$ ] afforded a colorless solid; yield: $83.0 \mathrm{mg}(93 \%)$; $\mathrm{mp} 139-141{ }^{\circ} \mathrm{C} ; R_{f}=0.22$ (pentane- $\left.\mathrm{Et}_{2} \mathrm{O}, 50: 50\right)$ [UV, $\left.\mathrm{KMnO}_{4}\right]$.

This procedure was also scaled up five-fold $(1.50 \mathrm{mmol}$ of 2,6-di-tertbutylphenol), and afforded 14a in a comparable yield [384 $\mathrm{mg}(86 \%)$ ]. IR (film): 3297, 2993, 2961, 2948, 2916, 2868, 1576, 1481, 1455, $1435,1423,1390,1359,1288,1266,1234,1212,1198,1172,1136$, $1116,1097,1042,1021,985 \mathrm{~cm}^{-1}$.

${ }^{1} \mathrm{H} \mathrm{NMR}\left(500 \mathrm{MHz}, \mathrm{CDCl}_{3}\right): \delta=8.50(\mathrm{~d}, J=1.9 \mathrm{~Hz}, 1 \mathrm{H}), 8.45(\mathrm{dd}, J=4.8$, $1.6 \mathrm{~Hz}, 1 \mathrm{H}), 7.49$ (dt, $J=7.7,1.9 \mathrm{~Hz}, 1 \mathrm{H}), 7.20(\mathrm{dd}, J=7.7,4.8 \mathrm{~Hz}, 1 \mathrm{H})$, $6.96(\mathrm{~s}, 2 \mathrm{H}), 5.12(\mathrm{~s}, 1 \mathrm{H}), 3.89(\mathrm{~s}, 2 \mathrm{H}), 1.41(\mathrm{~s}, 18 \mathrm{H})$.

${ }^{13} \mathrm{C}$ NMR $\left(126 \mathrm{MHz}, \mathrm{CDCl}_{3}\right): \delta=152.5,150.3,147.6,137.3,136.4$, $136.2,130.5,125.5,123.5,39.1,34.5,30.4$.

HRMS (ESI): $m / z[\mathrm{M}-\mathrm{H}]^{-}$calcd for $\mathrm{C}_{20} \mathrm{H}_{26} \mathrm{~N}_{1} \mathrm{O}_{1}$ : 296.2020; found: 296.2018

\section{p-Cresol (2b)}

To a solution of 2,6-di-tert-butyl-4-methylphenol (2a; $66.1 \mathrm{mg}$, $0.30 \mathrm{mmol})$ in toluene $(15 \mathrm{~mL})$ was added a solution of $\mathrm{AlCl}_{3}(240.0$ $\mathrm{mg}, 1.8 \mathrm{mmol})$ in $\mathrm{MeNO}_{2}(0.80 \mathrm{~mL})$ in one portion according to General Procedure B. Purification by column chromatography [silica gel, eluent load, pentane- $\mathrm{Et}_{2} \mathrm{O}$ (85:15)] afforded a colorless solid; yield: $27.1 \mathrm{mg}(84 \%) ; R_{f}=0.20$ (pentane- $\mathrm{Et}_{2} \mathrm{O}, 90: 10$ ) [UV, $\mathrm{KMnO}_{4}$ ].

${ }^{1} \mathrm{H}$ NMR $\left(400 \mathrm{MHz}, \mathrm{CDCl}_{3}\right): \delta=7.05(\mathrm{~d}, J=8.4 \mathrm{~Hz}, 2 \mathrm{H}), 6.74(\mathrm{~d}, J=$ $8.4 \mathrm{~Hz}, 2 \mathrm{H}), 4.88$ (br s, $1 \mathrm{H}), 2.28(\mathrm{~s}, 3 \mathrm{H})$.

${ }^{13} \mathrm{C}$ NMR $\left(101 \mathrm{MHz}, \mathrm{CDCl}_{3}\right): \delta=153.3,130.2,130.1,115.2,20.6$.

\section{4-Isopentylphenol (7b)}

To a solution of 2,6-di-tert-butyl-4-isobutylphenol (7a; $48.7 \mathrm{mg}$, $0.18 \mathrm{mmol})$ in toluene $(9 \mathrm{~mL})$ was added a solution of $\mathrm{AlCl}_{3}(144.0 \mathrm{mg}$, $1.08 \mathrm{mmol})$ in $\mathrm{MeNO}_{2}(0.48 \mathrm{~mL})$ in one portion according to General 
Procedure B. Purification by column chromatography [silica gel, eluent load, pentane- $\mathrm{Et}_{2} \mathrm{O}$ (90:10)] afforded a colorless oil; yield: $26.4 \mathrm{mg}(89 \%) ; R_{f}=0.26$ (pentane- $\mathrm{Et}_{2} \mathrm{O}, 85: 15$ ) [UV, $\mathrm{KMnO}_{4}$ ].

IR (film): 3333, 2955, 2930, 2901, 2869, 2849, 1614, 1597, 1513, 1468, 1453, 1441, 1384, 1366, 1336, 1265, 1237, 1219, 1171, 1115, $1097,1082,1016,855 \mathrm{~cm}^{-1}$.

${ }^{1} \mathrm{H}$ NMR $\left(400 \mathrm{MHz}, \mathrm{CDCl}_{3}\right): \delta=7.06(\mathrm{~d}, J=8.5 \mathrm{~Hz}, 2 \mathrm{H}), 6.76(\mathrm{~d}, J=$ $8.5 \mathrm{~Hz}, 2 \mathrm{H}), 4.81(\mathrm{~s}, 1 \mathrm{H}), 2.57-2.52(\mathrm{~m}, 2 \mathrm{H}), 1.58$ (app. nonet, $J=$ $6.6 \mathrm{~Hz}, 1 \mathrm{H}), 1.51-1.43(\mathrm{~m}, 2 \mathrm{H}), 0.93(\mathrm{~d}, J=6.6 \mathrm{~Hz}, 6 \mathrm{H})$.

${ }^{13} \mathrm{C}$ NMR $\left(101 \mathrm{MHz}, \mathrm{CDCl}_{3}\right): \delta=153.4,135.5,129.5,115.2,41.2,33.0$, 27.7, 22.7.

HRMS (ESI): $m / z$ [M - H] $]^{-}$calcd for $\mathrm{C}_{11} \mathrm{H}_{15} \mathrm{O}_{1}$ : 163.1128; found: 163.1128.

\section{4-(Tetrahydrofuran-2-ylmethyl)phenol (10b)}

To a solution of 2,6-di-tert-butyl-4-(tetrahydrofuran-2-ylmethyl)phenol $(\mathbf{1 0 a} ; 87.1 \mathrm{mg}, 0.30 \mathrm{mmol})$ in toluene $(15 \mathrm{~mL})$ was added a solution of $\mathrm{AlCl}_{3}(240.0 \mathrm{mg}, 1.80 \mathrm{mmol})$ in $\mathrm{MeNO}_{2}(0.80 \mathrm{~mL})$ in one portion according to General Procedure B. Purification by column chromatography [silica gel, eluent load, pentane- $\mathrm{Et}_{2} \mathrm{O}(80: 20$ to $70: 30)$ ] afforded a colorless oil; yield: $53.0 \mathrm{mg}(99 \%) ; R_{f}=0.21$ (pentane- $\mathrm{Et}_{2} \mathrm{O}$, 70:30) [UV, $\mathrm{KMnO}_{4}$ ].

IR (film): 3261, 3019, 2976, 2950, 2922, 2874, 2858, 1614, 1595, 1514, 1444, 1373, 1359, 1309, 1267, 1227, 1202, 1171, 1111, 1041, 1012, 954.

${ }^{1} \mathrm{H}$ NMR $\left(400 \mathrm{MHz}, \mathrm{CDCl}_{3}\right): \delta=7.04(\mathrm{~d}, J=8.4 \mathrm{~Hz}, 2 \mathrm{H}), 6.68(\mathrm{~d}, J=$ $8.4 \mathrm{~Hz}, 2 \mathrm{H}$ ), $4.94(\mathrm{~s}, 1 \mathrm{H}$ ), 4.08 (quint, $J=6.6 \mathrm{~Hz}, 1 \mathrm{H}$ ), 3.91 (ddd, $J=$ 8.3, 7.1, 6.5 Hz, $1 \mathrm{H}), 3.78(\mathrm{ddd}, J=8.2,7.6,6.1 \mathrm{~Hz}, 1 \mathrm{H}), 2.82(\mathrm{dd}, J=$ 13.7, $6.7 \mathrm{~Hz}, 1 \mathrm{H}), 2.69$ (dd, $J=13.7,6.2 \mathrm{~Hz}, 1 \mathrm{H}), 1.99-1.80(\mathrm{~m}, 3 \mathrm{H})$, $1.63-1.52(\mathrm{~m}, 1 \mathrm{H})$.

${ }^{13} \mathrm{C}$ NMR $\left(101 \mathrm{MHz}, \mathrm{CDCl}_{3}\right): \delta=154.5,130.6,130.3,115.4,80.6,68.0$, 41.1, 31.0, 25.7.

HRMS (ESI): $m / z[M+H]^{+}$calcd for $\mathrm{C}_{11} \mathrm{H}_{15} \mathrm{O}_{2}$ : 179.1067; found: 179.1068

\section{4-(Pyridin-3-ylmethyl)phenol (14b)}

To a solution of 2,6-di-tert-butyl-4-(pyridin-3-ylmethyl)phenol (14a; $89.2 \mathrm{mg}, 0.30 \mathrm{mmol})$ in toluene $(15 \mathrm{~mL})$ was added a solution of $\mathrm{AlCl}_{3}$ $(240.0 \mathrm{mg}, 1.80 \mathrm{mmol})$ in $\mathrm{MeNO}_{2}(0.80 \mathrm{~mL})$ in one portion according to General Procedure B. Purification by column chromatography (silica gel, solid load, $\mathrm{Et}_{2} \mathrm{O}$ ) afforded a colorless solid; yield: $32.0 \mathrm{mg}$ (58\%); mp $185-187^{\circ} \mathrm{C} ; R_{f}=0.25\left(\mathrm{Et}_{2} \mathrm{O}\right)$ [UV, $\mathrm{KMnO}_{4}$ ].

IR (film): 3063, 3041, 2956, 2921, 2852, 2791, 2723, 2674, 2607, 2360, 2341, 2324, 2189, 2166, 1990, 1610, 1593, 1579, 1512, 1481, 1454, 1433, 1420, 1379, 1348, 1319, 1294, 1278, 1267, 1246, 1204, $1187,1175,1124,1101,1047,1032,1009,956 \mathrm{~cm}^{-1}$.

${ }^{1} \mathrm{H}$ NMR (500 MHz, DMSO-d $_{6}$ ): $\delta=9.22(\mathrm{~s}, 1 \mathrm{H}$ ), 8.46 (br s, $1 \mathrm{H}$ ), 8.39 (br s, $1 \mathrm{H}$ ), 7.57 (d, J = 7.6 Hz, $1 \mathrm{H}$ ), 7.29 (br s, $1 \mathrm{H}$ ), 7.02 (d, J = $8.2 \mathrm{~Hz}, 2$ H), $6.68(\mathrm{~d}, J=8.4 \mathrm{~Hz}, 2 \mathrm{H}), 3.83(\mathrm{~s}, 2 \mathrm{H})$.

${ }^{13} \mathrm{C}$ NMR $\left(126 \mathrm{MHz}\right.$, DMSO- $\left.d_{6}\right): \delta=155.7,149.5,147.1,137.4,135.9$, 130.5, 129.5, 123.5, 115.3, 37.2.

HRMS (ESI): $m / z[M+H]^{+}$calcd for $\mathrm{C}_{12} \mathrm{H}_{12} \mathrm{~N}_{1} \mathrm{O}_{1}$ : 186.0913; found: 186.0914.

\section{Acknowledgment}

We are grateful to the EPSRC [J.R.F., T.J.D., Established Career Fellowship (EP/L023121/1)] and A*STAR, Singapore (C.B.C.) for financial support.

\section{Supporting Information}

Supporting information for this article is available online at http://dx.doi.org/10.1055/s-0035-1561439.

\section{References}

(1) For recent reviews, see: (a) Dobereiner, G. E.; Crabtree, R. H. Chem. Rev. 2010, 110, 681. (b) Bähn, S.; Imm, S.; Neubert, L.; Zhang, M.; Neumann, H.; Beller, M. ChemCatChem 2011, 3, 1853. (c) Pan, S.; Shibata, T. ACS Catal. 2013, 3, 704. (d) Gunanathan, C.; Milstein, D. Science 2013, 341, 1229712. (e) Ketcham, J. M.; Shin, I.; Montgomery, T. P.; Krische, M. J. Angew. Chem. Int. Ed. 2014, 53, 9142. (f) Obora, Y. ACS Catal. 2014, 4, 3972. (g) Yang, Q.; Wang, Q.; Yu, Z. Chem. Soc. Rev. 2015, 44, 2305. (h) Nandakumar, A.; Midya, S. P.; Landge, V. G.; Balaraman, E. Angew. Chem. Int. Ed. 2015, 54, 11022.

(2) (a) Chan, L. M. K.; Poole, D. L.; Shen, D.; Healy, M. P.; Donohoe, T. J. Angew. Chem. Int. Ed. 2014, 53, 761. (b) Shen, D.; Poole, D. L.; Shotton, C. C.; Kornahrens, A. F.; Healy, M. P.; Donohoe, T. J. Angew. Chem. Int. Ed. 2015, 54, 1642. (c) Frost, J. R.; Cheong, C. B.; Akhtar, W. M.; Caputo, D. F. J.; Stevenson, N. G.; Donohoe, T. J. J. Am. Chem. Soc. 2015, 137, 15664.

(3) Weissemel, K.; Arpe, H.-J. In Industrial Organic Chemistry, 3rd ed.; Wiley-VCH: Weinheim, 1997, 358.

(4) Kornblum, N.; Seltzer, R. J. Am. Chem. Soc. 1961, 83, 3668.

(5) (a) Lederer, L. J. Prakt. Chem. 1894, 50, 223. (b) Manasse, O. Ber. Dtsch. Chem. Ges. 1894, 27, 2409.

(6) (a) Lee, D.-H.; Kwon, K.-H.; Yi, C. S. J. Am. Chem. Soc. 2012, 134, 7325. (b) Walton, J. W.; Williams, J. M. J. Angew. Chem. Int. Ed. 2012, 51, 12166.

(7) Chen, Z.; Zeng, H.; Girard, S. A.; Wang, F.; Chen, N.; Li, C.-J. Angew. Chem. Int. Ed. 2015, 54, 14487.

(8) (a) For ${ }^{1} \mathrm{H}$ NMR data for 3, see: Baik, W.; Lee, H. J.; Yoo, C. H.; Jung, J. W.; Kim, B. H. J. Chem. Soc., Perkin Trans. 1 1997, 587. (b) For ${ }^{1} \mathrm{H}$ NMR data for 4, see: Barton, B.; Logie, C. G.; Schoonees, B. M.; Zeelie, B. Org. Process Res. Dev. 2005, 9, 62.

(9) $\mathrm{Bi}$ (cyclohexadienylidene)dione $\mathbf{4}$ is not isolable, but has been previously characterized in solution by ${ }^{1} \mathrm{H}$ NMR spectroscopy; see: (a) Winstein, S.; Filar, L. J. Tetrahedron Lett. 1960, 9. (b) Dyall, L. K.; Winstein, S. J. Am. Chem. Soc. 1972, 94, 2196.

(10) Although not observed in the $1 \mathrm{H}$ NMR spectrum of the crude product, it is likely that addition of $\mathrm{MeOH}$ to the benzoquinone methide is also a competitive process; as a result, elimination of methoxide may also be required prior to reduction. See: Omura, K. J. Org. Chem. 1991, 56, 921.

(11) (a) Gabrielsson, A. A.; van Leeuwen, P. P.; Kaim, W. W. Chem. Commun. 2006, 4926. (b) Jiang, B.; Feng, Y.; Ison, E. A. J. Am. Chem. Soc. 2008, 130, 14462.

(12) (a) Friedel, C.; Crafts, J. M. J. Chem. Soc. 1877, 32, 725. (b) Friedel, C.; Crafts, J. M. Bull. Soc. Chim. Fr. 1877, 530.

(13) Application of this methodology to other phenols has so far proven limited.

(14) (a) Matsuura, B. S.; Keylor, M. H.; Li, B.; Lin, Y.; Allison, S.; Pratt, D. A.; Stephenson, C. R. J. Angew. Chem. Int. Ed. 2015, 54, 3754. (b) Saleh, S. A.; Tashtoush, H. I. Tetrahedron 1998, 54, 14157.

(15) At this stage we cannot comment with any certainty whether an iridium mono- or dihydride species is formed.

(16) Phillips, J. P.; Gillmore, J. G.; Schwartz, P.; Brammer, L. E. Jr.; Berger, D. J.; Tanko, J. M. J. Am. Chem. Soc. 1998, 120, 195.

(17) Nishinaga, A.; Nakamura, K.; Matsuura, T.; Rieker, A.; Koch, D.; Griesshammer, R. Tetrahedron 1979, 35, 2493. 